\title{
THE STATUS OF STATE TRADING ENTITIES IN FRANCE
}

\author{
ANDREW REISH*
}

\section{INTRODUCTION}

State trading-the government conduct or control of commercial intercourseis not a new phenomenon conceptualized for the economic realities of the Twentieth Century. Rather, it is an established institution, having been extensively employed during the Middle Ages, most notably by a number of the Italian city-states. But with the onset of the mercantile revolution and the ensuing ascendancy of the laissez-faire philosophy, active state trading diminished to a point of virtual extinction. However, with the advent of the Twentieth Century, sovereign states began to venture into areas of interest to the state-economic, financial, industrial-that bore little resemblance to the spheres of activity formerly considered to fall within the functions of government. In addition, the Russian Revolution and the postWorld War II birth of the Socialist People's Republics in the East, with the subsequent disappearance of the traditional distinction between public and private enterprise, revitalized state trading and radically revised it to become an integral element of a political philosophy's all-encompassing economic system. ${ }^{\mathbf{1}}$ In the past few decades, the Western nations have begun to employ state trading as a tool of national policy to protect the welfare of their citizens and to assure continued economic progress.

As the volume of international commerce continually grows, the increasing utilization of state trading for the implementation of national goals and policies has necessarily caused reflection on the presently existing tenets and doctrines of national legal systems and international law. This large-scale introduction of state trading enterprises into commercial markets raises important questions about the nature of these state-created and state-controlled entities. Is the state trading enterprise considered an organ of the state, a distinct legal entity functioning as an organization similar to a private enterprise, or a combination of the two? In identifying the entity, must the established legal definitions used in the identification process also be re-examined and modified to reflect the economic realities of modern commerce? Finally, how should the entity be treated before foreign courts and in foreign jurisdictions?

This paper will examine how the courts and jurists of one particular country, the Republic of France, have attempted to answer these questions as seen through the development of the judicial treatment given to Soviet and East European state trading enterprises in France. The development will be traced through three ill-

- B.S., Lehigh University, I970; J.D., Duke University, I973.

${ }^{2}$ See Allen, State Trading and Economic Warfare, 24 Law \&: Contemp. Prob. 256 (I959); Humphreys, The Economic Consequences of State Trading, 24 Law \& ConTEMp. Prob. 276 (I959). 
defined periods: (I) absolute immunity, (2) the retreat to the doctrine of restrictive immunity, ${ }^{2}$ and (3) restrictive immunity under treaty law. This development will be shown through the use of treaties and French case law. It should be pointed out, however, that although the author applies to the French decisions the method which he would use in analyzing a series of cases decided by common law jurisdictions, regard must be made to the absence of such a rigid doctrine of precedent as exists in common law jurisdictions. Even though the authority of precedent as such in a civil law system is admittedly not the same, for courts are not bound by previous decisions, case law probably has more influence over French courts than French commentators are sometimes willing to admit.

Prior to examining the treatment of state companies in France, a brief overview of the elements of an East European state trading enterprise is required. A state trading company is basically identical to any other company except that the state happens to be the owner. It is an owner which not only wants to direct economic development but to control it as well. Under sections 23 to 40 of the Russian Civil Code, which constitutes a skeletal corporation law controlling the status, powers and functions of judicial persons, an enterprise is answerable for its own obligations only to the extent of the property it holds; it is not liable for the debts of the state or of other operating entities. ${ }^{3}$ Comparable provisions are found in the legislation of other East European countries. ${ }^{4}$ Furthermore, since under the Soviet constitution, the external trade of the Soviet Union is a state monopoly, Soviet entities engaged in foreign trade are considered essentially state organs, forming part of, and directly representing the government of the U.S.S.R. Hence, by the use of state trading enterprises, the state attempts to attain maximum control and benefit while at the same time limiting its liability. It was this attempt carried to the extent of claiming sovereign immunity which embroiled the state companies in French litigation in the rg20's and r930's.

Evolution of the Immunity Doctrine in France

\section{A. Absolute Immunity}

During the Nineteenth Century, the primary concept concerning the liability of a sovereign to legal action in a foreign jurisdiction was that of absolute immunity: the plea of immunity is available in every instance in which the person or property of a foreign state is impleaded in the courts of another state, irrespective of the

\footnotetext{
${ }^{2}$ See Lolive, L'Immunité de Juridiction des Etats et des Organizations International, 84 RecueIt DEs Cours 205 (I953) [hereinafter cited as Lolive].

${ }^{3}$ S. Pisar, Coexistence and Commerce: Guidelines for Transactions Between East and West 265 (1970). See also Szászy, The Proper Law of the Contract in Trade Between Eastern Europe and the West: The Position of East European Socialist States, I8 INT'2 \& CoMP. L.Q. 103 (1969).

« See R.S.F.S.R. Grazh. Kod. (Civil Code), §32; Hungarian Civil Code, \$31 (1959); Polish Civil Code, art. 40 (I964); Bulgarian Law on Enterprise, art. 6 (1960).

${ }^{5}$ See Lauterpacht, The Problem of Jurisdictional Immunities of Foreign States, 28 BRIT. Y.B. INT'L L. 220, 22I (I95I) [hereinafter cited as Lauterpacht].
} 
nature of the act which gave rise to the proceeding. This obligation of the courts to not only decline jurisdiction over foreign states, but also to decline execution on the property of foreign states, is firmly grounded in the principles of the independence, the equality, and the dignity of states. Following from these principles, the maxim, par in parem non habet imperium, meaning no state could claim sovereignty over any other state, required courts to decline jurisdiction over foreign states or necessarily violate the fundamental canons of international law. These principles which underlie the immunities from jurisdiction and from execution received broad application in France when the Cour de cassation, after numerous lower court decisions, ${ }^{6}$ pronounced in Le Gouvernement espagnol v. Casaux the viability of absolute immunity in France.

In Casaux, the court, in granting the Spanish government immunity from jurisdiction on the basis of the reciprocal independence of sovereign states, rejected the attempted distinction between Etat puissance publique (state as a public power) and Etat personne privée (state as a private person). The court held that the contracted purchase of boots by the Spanish government for use of the Spanish army could not be distinguished as a private act so as to render Spain amenable to the jurisdiction of the French courts. The court announced that any and all contractual obligations of a foreign state, regardless of the nature, are immune from jurisdiction. However, the holding of absolute immunity is not all-encompassing because Casaux pertains only to the purchase of goods and not to the commercial activities of a foreign state. Thus, since buying is not necessarily trade unless the goods are purchased for the purpose of commercial resale, Casaux cannot definitely be cited as authority for the adoption of absolute immunity vis-à-vis trading activities. ${ }^{\mathrm{s}}$

\section{B. Restrictive Immunity}

About rgoo, a judicial practice began to evolve in various West European jurisdictions which denied immunity from jurisdiction and from execution to a foreign state when it was made a respondent with respect to an act of a commercial or, so-called, private nature. The new practice appeared principally as a result of the increasing involvement of the sovereign state in the international market place as merchant, industrialist, banker, and transporter in direct competition with private enterprise. ${ }^{9}$ This enlarged role of states as entrepreneurs in international trade exposed a major weakness in the traditional rule of absolute immunity: the inequality before the law

\footnotetext{
${ }^{\circ}$ Solon v. Gouvernement égyptien, [1849] Recueil Periodique et Critique [D.P.] I. 7 (Trib. civ., Seine); Le Gouvernement d'Espagne v. La Maison Bolguerie de Bordeaux, [1849] D.P. I. 6-7, [1849] Recueil Général de Lois et des Arrêts [S. Jur.] II. 85 (Trib. civ., Seine); Blanchet v. Gouvernement d'Haiti, [r849] D.P. I. 6, [I849] S. Jur. II. 83 (Trib. civ., Havre).

${ }^{7}$ [1849] D.P. I. 5, [ 1849 ] S. Jur. I. 81 (Cass. civ. Ire). (This case is often cited as Le Gouvernement espagnol v. Lambege et Pujol.)

${ }^{8}$ S. Sucharitiul, State Immunities and Trading Activities in International Law 209 (x959) [hereinafter cited as SucharitKuL].

${ }^{\circ}$ Lolive 214 .
} 
arising from the exemption of state enterprises from suit and law. To alleviate this denial of right to redress for breach of contract or related abuses, and to meet the exigencies of international business, jurists formulated the theory of restrictive immunity.

The theory of restrictive immunity, as elaborated by the early courts, is founded on the basis of a legally significant distinction between the acts of the state effected in its status as sovereign or in the exercise of public power, jure imperii, and those acts performed as a private person, jure gestionis. ${ }^{10}$ According to this theory, a foreign state may invoke immunity in the courts of another sovereign state if the litigation arises in connection with transactions of the former type but is denied immunity in actions concerning transactions of the latter type. This distinction is based on the theory that the sole function of the state is to govern: to exercise executive, legislative, and judicial authority. By entering the market place in a capacity normally reserved for individual enterprise, the state forfeits its claim to be accorded the dignity and equality of a sovereign state, either because its transactions fall outside the scope of sovereign immunity or because the state is presumed in law to have waived its immunity when engaged in such activities. But the seeming simplicity of the theory belies the difficulty encountered in its actual application.

An initial difficulty concerning the doctrine of restrictive immunity is found in the lack of dependable criteria upon which to truly distinguish transactions jure gestionis. In attempting to distinguish between acts jure imperii and acts jure gestionis, the courts of different countries-and occasionally courts of the same country-have treated the same kind of activity in different ways. Upon what conditions does one base the distinction ? $^{11}$ A deeper underlying difficulty of implementation is that the concept of the state at the time of the theory's formulation has been altered. With the rise of socialist states and the growing involvement of nations in their domestic economies, it is no longer accepted that the economic activities of the state-such as state management of industry-are necessarily of a purely private-law nature, that they are jure gestionis or that in them, a state acts like a person.12 Under the new political interpretation of the state, the state acts as a public person for the general purpose of the community as a whole, and thus, especially in socialist economies, all acts jure gestionis are acts jure imperii to the extent that the distinction between the two cannot be placed on a sound logical basis.

However, the fact that the distinction underlying restrictive immunity is open to serious objections does not mean that the principle of absolute immunity-a principle which is productive of inconvenience and resentment in international commerce-is the alternative. ${ }^{13}$ With this in mind, the French experience with restrictive immunity will be considered.

\footnotetext{
${ }^{10}$ Id. at 215.

${ }^{11}$ For a searching attempt to establish criteria see Weiss, Compétence oil l'incompétence des tributnaux à l'égand des Etats Etrangers, I RecueIL DEs Cours 525 (I923).

12 Lauterpacht 224.

${ }^{13} \mathrm{Id}$. at 226 .
} 
Growing governmental intrusion into economic life everywhere and the emergence of a country practicing total state commerce provoked a French reaction against the concept of absolute sovereign immunity. The French courts, which had begun a retreat to a restrictive immunity posture prior to the full scale invasion of Soviet Trade Delegations into Western Europe, took the position of segregating governmental activities which warranted immunity from those which did not. ${ }^{14}$ In regard to the Soviet Trade Delegation, the French courts began to draw distinctions between sovereign acts and commercial acts, despite the disputations of the Soviet Union that all acts of its Delegation, as an integral arm of the state, were acts of the state and thus immune to the jurisdiction of French courts. ${ }^{15}$ The disinclination to grant immunity in matters jure gestionis reached clear expression in Société de Gostorg et la Représentation Commerciale de l'U.R.S.S. v. Association FranceExport. ${ }^{16}$

In Association France-Export, a Russian trust based in Moscow entered into a commercial lease with a French company, using as intermediary the Trade Delegation in France. This lease related to the Association's participation in a trade exhibition to be held in Moscow. Upon default by and judgment against the gostorg, the Tribunal Civil de la Seine allowed an attachment of the Trade Delegation funds, through somewhat strained agency reasoning, for the acte de commerce of the gostorg. ${ }^{17}$ The Cour de cassation, in affirming the attachment by a succinct opinion, justified the denial of sovereign immunity on the widespread commercial activities of the Trade Delegation. However, it should be noted that the court extended jurisdiction only to the assets of the Trade Delegation, an organ of the Soviet state, while not extending jurisdiction to any other assets of the Soviet state. Thereby, the Trade Delegation was endowed with a special status, a suable state organ.

Once approved by the Cour de cassation, the amenability of the Trade Delegation to the local French jurisdiction was followed by a series of decisions known as the Soviet Cases. In Représentation Commerciale de l'UR.S.S. v. S.A. des Entreprises Gère et Banque Commerciale pour l'Europe $d u$ Nord, ${ }^{18}$ Rudmetalltorg, a Soviet corporation, made a contract with Gère through the Russian Trade Delegation in Paris. When Rudmetalltorg defaulted on the contract, the court allowed attachment of the Delegation's assets. In rejecting a motion by the Delegation to quash the attachment, the court selectively examined Soviet law to conclude that, despite Rudmetalltorg's corporate articles, the corporation had so little actual independence that the Trade Delegation was not an agent, but a principal liable under the contract. In

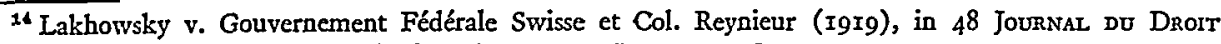
INTERNATTONAI I79 (I92I) [hereinafter cited as - JouRNaL -].

${ }^{15}$ Bishop, General Course of Public International Law, 1965, II5 ReCueIL Des Cours I52, 226 (1965).

${ }_{10}$ [1929] D.P. I. 73, [1930] S. Jur. I. 49 (Cass. civ. Ire). This case was appealed from Cour d'appel de Paris, Judgment of Nov. 19, 1926, [1927] Recueil Habdomadire de Jurisprudence [D.H. Jur.] 56, 56 Journaz 1042 (1929).

17 Sucharitkul. 158.

${ }^{18}$ Judgment of Jan. 7, I93I (Trib. civ., Seine), in 58 Journal 413 (I93I).
} 
extending liability to the Trade Delegation, however, the court did not examine Soviet law for the purpose of determining whether the Trade Delegation was truly a governmental organization entitled to immunity. In Magasins Universels de la R.S.F.S.R. v. Kahn, ${ }^{19} \mathrm{Kahn}$ obtained an attachment against both the Trade Delegation and Magasins Universels in respect to a debt owed him by Magasins Universels. Rejecting Magasins Universels' defense of not having been properly served with notice of the attachment, such notice having been served upon the Trade Delegation in Paris, the court held that under Soviet law the Trade Delegation obligatorily represents all Soviet corporations abroad and as such, service on it is service on Magasins Universels.

Finally in Banque Arnus, \& Cie v. La Représentation Commerciale de l'U.R.S.S., ${ }^{20}$ in an action for damages for repudiation of a contract signed by a Soviet syndicate and countersigned by the Trade Delegation, the court held the Trade Delegation jointly liable with the syndicate, notwithstanding contract terms which seemed to exonerate it. Furthermore, the court held the Trade Delegation responsible for all commercial transactions concluded by any Soviet agency outside the U.S.S.R. on the grounds that the foreign trading activities of the Soviet Union were defined in Soviet laws as state acts. Thus the court held the Trade Delegation was necessarily the commercial agency of the Soviet state trading monopoly. Therefore, the Trade Delegation got the worst of both worlds; it was sufficiently a separate entity to be distinguished from the Soviet state, but it was not sufficiently a separate entity to distinguish itself from other commercial entities of that state. ${ }^{21}$

The conclusion of this series of cases was La Représentation Commerciale de l'U.R.S.S. v. Société francaise Industrielle et Commerciale des Petroles (Groupe Malopolska). ${ }^{22}$ It was precipitated by the Soviet Army's seizure of French owned oil wells situated in Poland. In taking these commercial assets for the benefit of the state trade monoply, the court concluded that the Soviet Union acted not as a sovereign state but as a merchant. Thus, the court upheld an attachment of the Trade Delegation's assets, deeming the Delegation to have an existence and individuality capable of having executions placed upon it as an organ of a state which had acted in the capacity of an entrepreneur. ${ }^{23}$

The special treatment given by French courts to cases involving the Soviet government can also be seen in Société Téfimo $v$. Représentation Commerciale de l'U.R.S.S. ${ }^{24}$ and in Chaliapine v. l'U.R.S.S. et Librarie Brenner. ${ }^{25}$ In Sté Téfimo,

\footnotetext{
${ }^{10}$ Judgment of Feb. Io, I93I (Trib. civ., Seine), in 58 Jounnal 4I2 (1931).

${ }^{20}$ Judgment of Mar. I6, I93 I (Trib. civ., Seine), in 58 Journal 416 (193I).

${ }^{21}$ Hamson, Immunity of Foreign States: The Practice of the French Courts, 27 Bnir. Y.B. INr'L L. 293, 313 (1959) [hereinafter cited as Hamson].

${ }_{22}^{2}$ [1940] D.H. Jur. 68, [1940] Gazette du Palais I. 44 (Trib. civ., Seine).

${ }^{23}$ Hamson 313.

24 Judgment of May 17, 1934 (Cour d'appel, Paris), in 61 Journal 633 (1934).

${ }^{25}$ [1937] D.P. I. 63, [1937] S. Jur. I. I04 (Cass. civ. Ire). See also Dunbar, Controversial Aspects of Sovereign Immunity in the Case Law of Some States, 132 Recuell Des Cours 197, 215-16 (1971) [hereinafter cited as Dunbar].
} 
a contract concluded in Paris between the director of Téfimo and a representative of the nationalized Jewish Theater of Moscow had been breached. The Cour d'appel de Paris held that although the Jewish Theater was an organ of the state, commercial transactions engaged the commercial responsibility of the state to which there was no jurisdictional immunity. ${ }^{26}$ Hence, any liabilities of the Jewish Theater were liabilities of the state which, in administering foreign trade through the Trade Delegation, caused the Delegation to be answerable before French courts. ${ }^{27}$

In Chaliapine, the singer, Chaliapine, brought an action for damages for breach of copyright against the Russian Trade Delegation in Paris, which had introduced into France and had sold through the Librarie Brenner in Paris, an abridged and mutilated edition of his book, Pages de Ma Vie. In applying the principles of limited immunity, the Cour de cassation rejected the Delegation's plea that the control exercised by the Soviet government over the export of books made such an export an act of sovereignty. Furthermore, the court held that these were acts not of sovereignty, but those that arose from commercial transactions. Hence, the Trade Delegation, which was responsible for those transactions, was not immune from the jurisdiction of the French courts. The court said: "This is not a question within the domain of political affairs, but of operations of a strictly commercial character which the courts can consider without interference with Russian State administration. The publication of the memoirs of a singer is in no way a political act ....."28

The Chaliapine case represents the culmination of French judicial efforts to find a solution to the problem of immunity of an Etat commercant which had monopolized its foreign trade. By the application of the acte de commerce theory the French courts discovered sound basis not only for assuming jurisdiction over the Trade Delegation and permitting the execution of judgments against its assets, but also for holding the Trade Delegation, admittedly a state organ, responsible for all commercial activities of the U.S.S.R. Therefore, the Delegation was deemed responsible for all commercial activities of the U.S.S.R. in France even though the transactions in question were not effected by or through it, but by other separate incorporated agencies of the Soviet Union. ${ }^{29}$

Despite this practical solution, the French courts recognized certain limitations on their jurisdiction. In La Représentation Commerciale de l'U.R.S.S. v. Sakharoff, ${ }^{30}$ the Cour d'appel de Paris overturned a lower court decision which held that the French courts could exercise jurisdiction over an employment contract between the Trade Delegation and one of its Russian employees. The court of appeals, while recognizing its jurisdiction in actions concerning cases arising out of matters transacted by the Trade Delegation in buying and selling of goods, disclaimed jurisdiction

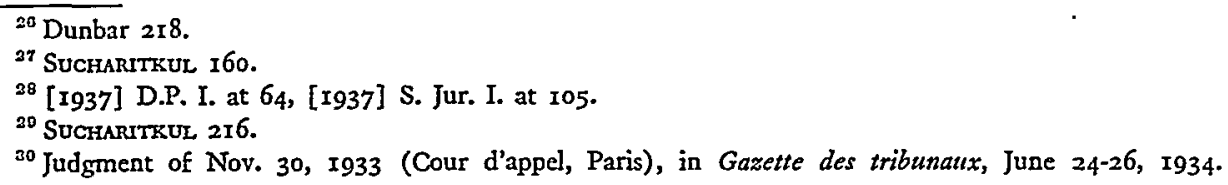


in matters where the Delegation conducted itself in its official capacity. Thus, the Trade Delegation had retained its character as an organ of a sovereign state and not its commercial character in its relations with Sakharoff, a former Trade Delegation official.

\section{II}

\section{Restrictive ImMunity Under Treaty LaW}

\section{A. The Treaties and Their Interpretation}

After the destruction of absolute immunity and the special treatment given the Trade Delegation, the Soviet Union sought to remove certain fact situations from the jurisdiction of the general principles of international law. In this regard, the Soviet government concluded bilateral treaties, beginning with the Franco-Soviet Commercial Agreement of January II, I934, ${ }^{31}$ and continuing in renewals thereof until December 3r, r939. A provision of the Agreement which sought to limit the liability of the Trade Delegation provided that all disputes relating to commercial transactions entered into by the U.S.S.R. Commercial Delegation in France should be within the jurisdiction of French tribunals and resolved according to French law. ${ }^{32}$ With a standard by which to gauge their accountability before the French courts, the Soviets altered their contracting procedure so as to fall outside the reach of the provision. During the effectiveness of the Treaty, the Cour d'appel d'Aix, reflecting the restrictive nature of the new Treaty provisions, decided Socifros $v$. I'U.R.S.S. ${ }^{33}$ The court held that it would be contrary to French notions of public order to allow execution against the Soviet Union when execution against the Trade Delegation had been limited by the Treaty. However, after the expiration of the Agreement of December 3I, 1939, the French courts, returning to their holdings prior to the Agreement, held that acts of the Trade Delegation could only be considered as acts of commerce to which the principle of state sovereignty could not be applied. ${ }^{34}$ Then the war intervened.

Shortly after the war, a reciprocal trade agreement was signed with an accompanying provision relating to the status of the Trade Delegation in France. ${ }^{35}$ The Soviet Union by the agreement assumed responsibility only for those guaranteed transactions concluded in the name of the Trade Delegation and by an authorized person thereof. An unguaranteed transaction bound only the particular Soviet corporation to the extent of its assets. In addition, a guaranteed contract, unless it contained a compromise or forum-selection clause, was allowed to be brought before French courts and resolved by French laws with any execution being chargeable

\footnotetext{
31 x67 L.N.T.S. 349 .

${ }^{82}$ Decree of Jan. 23, 1934, [1934] Journal Officiel de la République Français [J.O.], Jan. 24, x934. See Dunbar 2x7 n. 22.

${ }^{83}$ [1939] D.P. II. 65,66 (Cour d'appel, Aix).

"Représentation Commerciale de l'U.R.S.S. v. Société française Industrielle et Commerciale des Petrole, [r940] D.H. Jur. 68, [1940] Gazette du Palais I. 44 (Trib. civ., Seine).

${ }^{85}$ Decree of June 20, 1946, [I946] J.O. 1505, 73-76 Journal 402 (1946-49).
} 
to all Soviet interests in France, with certain exceptions. Furthermore, the Trade Delegation was not required to register pursuant to French business registration laws.

A similar Franco-Soviet agreement on trade was signed on September 3, 195x, of which article ro read:

The Commercial Representation of the U.S.S.R. in France shall enjoy privileges and immunities ... with the following exceptions:

Disputes in connection with commercial transactions concluded or guaranteed on French territory by the Commercial Representation of the U.S.S.R. . . . shall ... fall within the competence of French tribunals and shall be decided in accordance with French legislation, unless there be any provision to the contrary in the clauses of each particular contract or in French law.

In addition, although the agreement disavowed interim measures of protection against available assets of the Trade Delegation in France, it reaffirmed the rule that execution may be levied against such assets as were not properly used in diplomatic representation, provided the guaranteed contract provision of the agreement was followed.

Shortly after the agreement, a case arose which was reminiscent of the Socifros case decided during the treaty period of the I930's. In Captaine de Volochaevsk $v$. Société Nouvelle des Apparaux de Rouen, ${ }^{37}$ as in Socifros, the Soviets opposed the attachment of a ship owned by the U.S.S.R., claiming that it was immune from execution. In Socifros immunity from execution was granted on the grounds that the ship was the property of a sovereign state. The court in Captaine de Volochaevsk, while agreeing in principle that execution could not be levied against a state, held that the attachment was legally justified since the ship was not being employed in a public service of the foreign state but on lease to a third party. ${ }^{38}$ Again the French courts took the view previously expressed in Chaliapine that the dispute arose from a commercial operation which should not be protected by immunity from execution.

\section{B. The Nationalization Decisions}

At the same time as France re-established its commercial accords with the U.S.S.R., more nations were fast becoming homes for socialist state trading companies. As the new communist regimes in Eastern Europe were developing their state trading corporations, the governments were also nationalizing the private industry of their respective countries. The usual method of nationalization was expropriation or confiscation without indemnification of the private owners. Though the effect of the nationalization without indemnification on the firm's assets located within the country of nationalization is not a matter within the jurisdiction of

\footnotetext{
${ }^{30}$ Decree of Sept. 3, x951, in 80 Journat 502, 506 (x953).

${ }^{37}$ Judgment of Apr. Ir, 1953 (Trib. civ., Rouen), in Le Droit Maritime francais 405 (r953).

${ }^{38}$ Dunbar 254-55.
} 
foreign courts, these courts are competent to consider the effect of the nationalization on the foreign-based assets of the nationalized firm within the court's jurisdiction. This matter has been the subject of frequent litigation in France.

In Societte Hardmuth, ${ }^{39}$ the Cour d'appel de Paris had occasion to consider this question in connection with the nationalization of a Czech firm by the Czech government. The French-based assets of the firm were organized under French law into a company considered by its creators to be the successor of the nationalized company. A suit was brought by the nationalized Czech firm to have an administrator appointed to supervise and preserve all the French assets for the benefit of the Czech firm. The court divided the French assets into two categories: (I) corporal property for which no administrator was appointed because of the international law tenet that property located outside of the country of nationalization is not effected by the nationalization when there is no indemnification, and (2) industrial property which required an administrator because both countries were signatories of the Convention of Paris of 1883 which protected industrial property rights. ${ }^{40}$

A second case which dealt with the extraterritoriality of nationalization was the French branch of the Zeiss litigation, Fondation Carl Zeiss, Meidenheim v. Fondation Carl Zeiss, Jena. ${ }^{41}$ Eighty-four Zeiss trademarks were registered in France between 1926 and I944. They were sequestered for the benefit of France as war reparations by the Law of March 2I, I947, and were authorized for return to their rightful owners by the Law of January 4, I955. Zeiss, Heidenheim, which represented directors who moved from the Russian occupied zone and set up the company in Heidenheim, West Germany, claimed the trademarks as did Zeiss, Jena, which represented the company which remained in Jena and which was confiscated by the state and later re-organized by the Russian authorities. The Cour de cassation held that Zeiss, Heidenheim was the proper successor to the trademarks because Zeiss, Heidenheim represented the continuation of the original Zeiss, Jena, the East German branch of which was destroyed by Soviet confiscation and re-organization. Further, it ruled that even if the Soviet confiscation had vested the state with the company's rights, trademarks are territorially bound and hence those in France could not automatically pass by confiscation. The court announced the general principle that nationalization without indemnity is against the public order of France and hence would be without effect in France.

\section{Recent Trade Agreements}

In the early 1960 's, France turned increasingly towards the East in pursuit of markets and trading partners. To aid in its trade offensive toward Eastern Europe,

\footnotetext{
${ }^{39}$ Judgment of Dec. 2, I950 (Cour d'appel, Paris), in 44 Revue CrutrQue de droir International PrIV́́ 500 (r955) [hereinafter cited as - ReVOE - ].

${ }^{10}$ Each member country owes the individuals and companies of the other signatories the same de. gree of protection as it provides for its own.

[1966] Bull. Civ. III. 126, 56 REvuE I47 (1967) (Cass. civ. com.). See Treves, Les nationalisationts en Allemagne de l'Est et le fondation Carl Zeiss, 56 RevUE 23 (1967).
} 
France had sought to minimize all legal obstacles to commercial intercourse. By virtue of their judicially eventful past regarding the treatment of state trading interests, the French realized, not surprisingly, that merchants have a tendency to trade in an inverse proportion to the degree of uncertainty in their contractual rights and obligations with state trading enterprises. To minimize the uncertainty and thereby maximize commercial interaction, the French have entered into numerous bilateral agreements of a consular or commercial nature with the U.S.S.R. and every nation of Eastern Europe. ${ }^{42}$

The trade agreements entered into by the French government were of wide variety, but with many similar provisions. Possibly in an attempt to contain the French courts' expansion of the limitations on the immunity of foreign state trading interests, the agreements usually contained articles pertaining to the rights and the obligations of consular or commercial representatives in the respective signatory countries. With those countries with which France has consular relations, the treaties provided for legal immunities for the consular or commercial representatives, unless they enter into private activities of a commercial nature. ${ }^{43}$ France has executed with every nation of Eastern Europe economic or commercial treaties which most commonly provided for a mixed commission consisting of Frenchmen and nationals of the other signatory nation. The commission is to implement and augment the economic or commercial interchange; that is, to work for the elimination of legal impediments to unobstructed trade. Numerous examples of the above mentioned provisions are illustrated in trade agreements concerning technology, ${ }^{44}$ patents, ${ }^{45}$ shipping, ${ }^{46}$ and commerce and economics ${ }^{47}$ which were entered into by France and the Soviet Union.

\section{IV}

\section{Recent Jubrcial Refinements}

At the same time as the French executive and legislative branches of government were executing trade agreements defining the bounds of sovereign immunity accorded foreign states before domestic courts, the French judiciary itself was announcing decisions bearing on the same issue. In Société S.A.P.V.I.N. v. AgroExport, ${ }^{48}$ the parties signed a contract which contained a provision commonly used

\footnotetext{
12 Consular conventions: Bulgaria, Czechoslovakia, Hungary, Rumania, U.S.S.R. Scientific, technological, and economic cooperation accords: Bulgaria, Czechoslovakia, Hungary, Poland, Rumania, U.S.S.R., Yugoslavia. Commercial accords: Albania, Bulgaria, Czechoslovakia, East Germany, Hungary, Poland, Rumania, U.S.S.R., Yugoslavia.

${ }^{43}$ Decree of Oct. 22, 1967, [1967] J.O. 19412, Recueil des Traitís Et Accords DE IA France ANNÉE I967, at 644-48 (1971).

"Decree of Feb. 28, I968, [1968] J.O. 2893.

${ }^{45}$ Decree of Apr. 21, I967, [I967] J.O. 4589, [I967] Recueil Dalloz [D.S.L.] 2Io.

${ }^{40}$ Decree of Apr. 20, I967, [Ig67] J.O. 9499, 56 Revue 804 (I967).

${ }^{17}$ Decree of Oct. 6, 1969, [1969] J.O. I0250, 58 ReVUe 819 (I969).

${ }^{48}[1968]$ Bull. Civ. I. 74, 58 Revue 97 (I969) (Cass. civ. lre).
} 
in an effort to prevent the assertion of the claim of sovereign immunity. Under the provision, the parties agreed to resolve any differences before a pre-selected arbitration board rather than before a court of law. In this case, S.A.P.V.I.N., a French company contracting to purchase Yugoslav wine, specified that differences were to be arbitrated in Belgrade. When S.A.P.V.I.N. was ordered by the arbitration court to pay damages for its breach of contract, it sought to nullify the arbitration provision so as to prevent the execution of the award on its French assets. The Cour de cassation held that since S.A.P.V.I.N. had entered into the contract willingly, the court would not alter the arbitration award unless it was procedurally erroneous or substantially fraudulent.

Banque d'Etat Tchécoslovaque et Statni Banka v. Englander ${ }^{40}$ presented a more refined question of immunity from execution. In I948 a Czech citizen in Czechoslovakia deposited funds in the Tatra Bank to be sent to Englander who was domiciled in France. In I950, the Statni Bank, which had been created as a state bank to carry out all measures connected with the Czechoslovakian monetary and financial system, including that of state payments abroad, assumed the rights and obligations of the Tatra Bank which had been unable to send abroad the funds belonging to Englander. On the failure of the Statni Bank to pay him, Englander obtained a judgment from the Cour d'appel d'Aix, declaring that the Statni Bank was in his debt to the extent of the funds originally deposited. In pursuance of this judgment, the Tribunal de grand instance de Marseille authorized the attachment of the funds belonging to the Statni Bank which were in the custody of the Banque commerciale pour l'Europe du Nord.

When this order was presented to it, the Cour d'appel d'Aix took a different view and refused to permit execution of the judgment against the funds of the Statni Bank, choosing instead to grant the Bank immunity from execution. ${ }^{50}$ The court considered that the funds of the Statni Bank deposited in foreign countries belonged in part to the Czech state. These included monies used in connection with Czech commercial enterprises, the upkeep of diplomatic missions, and the payment of financial contributions of the state to various international organizations. ${ }^{61}$ Since, in this suit, it was impossible to distinguish between the public and private funds held by the Banque commerciale in France, to allow attachment would threaten to deprive a foreign state of resources necessary to meet obligations incurred in the exercise of its puissance publique.

Upon appeal to the Cour de cassation, the decision of the Cour d'appel d'Aix was annulled. The court held that in basing immunity from execution on ( $I$ ) the impossibility of discriminating between public and private funds kept by a state bank and (2) the possibility of depriving a foreign state of resources needed for its public functions, the court of appeals failed to give une base légale for its decision.

\footnotetext{
${ }^{6}$ [1969] Bull. Civ. I. 52, No. 69, 96 Journal 923 (1969) (Cass. civ. Ire).

${ }^{50}$ Judgment of Feb. 14, I966, in 93 Journal 846 (1966).

${ }^{61}$ Dunbar 235.
} 
Consequently the decision below was quashed and the case sent down for rehearing before the full court of appeals in Nimes. ${ }^{52}$

In Clerget $\nu$. Représentation commerciale de la Republique démocratique du Vietnam, ${ }^{53}$ Clerget sued for wages earned while he had been employed by the Democratic Republic of Vietnam (North Vietnam) in a mining enterprise. The Cour d'appel de Paris, prior to a trial on the merits of the claim, rejected the defendant's contention that a conseil de prud'hommes was incompetent to hear this litigation. The court concluded that this kind of employment contract did not amount to un acte de puissance publique (an act of public power), but was un acte de gestion (an act of management) such as a commercial or industrial enterprise would pursue in the course of its normal activities. In pursuance of the above determination, Clerget obtained a default judgment against the defendant.

In order to obtain a provisional attachment to satisfy the default judgment, Clerget proceeded against funds which were held by the Banque commerciale pour l'Europe du Nord. These funds were held for the benefit of the Democratic Republic of Vietnam or its commercial representation and, most notably, for the Banque du commerce exterieur du Vietnam, an emanation of the Democratic Republic of Vietnam. The Tribunal de grande instance de la Seine decided that the exception to the rule of immunity from jurisdiction and execution in commercial transactions with states which have a monopoly over external commerce should not be invoked by the plaintiff. ${ }^{54}$ The court held that the debt did not arise from a commercial transaction entered into with the commercial delegation of the Democratic Republic. The debt arose from a contract of management and direction signed in Hanoi by the plaintiff and a vice-minister of the Democratic Republic without any participation of the commercial delegation which, in fact, did not come into existence until later. Moreover, the plaintiff considered himself as the representative in France of the Democratic Republic. The Cour d'appel de Paris affurmed: the lower court decision but recognized that foreign states and their organs when. acting on their account enjoy immunity only in respect of public acts. In the court's view, immunity is based on the nature of the activity and not on the character of the person performing it. ${ }^{55}$

After eight years of litigation, the Cour de cassation apparently settled the issue of the reach of immunity from execution when it announced its affirmation of the decision pronounced by the court of appeals. ${ }^{56}$ The court declared that in the name of sovereignty and independence of foreign states, immunity should be granted even for the payment of debts having their origin in acts of management relating to private enterprise. However, the court, in upholding immunity from execution, took care to

\footnotetext{
E2 No record of the decision of this court could be found.

${ }^{\text {E3 [ }}$ I971] Bull. Civ. I. 237, No. 278, 6r RevUe 3Io (r972) (Cass. civ. lre).

5u Judgment of Mar. 15, 1967, in 95 Journal 55 (1968).

${ }^{65}$ Judgment of June 7 , 1969 , in 96 JournsL 894 ( 1969 ).

80 [197I] Bull. Civ. I. 237, No. 278, 6x Revue 310 (1972).
} 
note that the objects of the attachment action, the bank funds, could not be attached since the origin and destination of the funds could not be determined.

\section{Conclusion}

How does one balance the needs of international business, which requires that all enterprises engaged in international transactions be recognized as equal before the law, against the reality of co-existing legal systems which provide that enterprise constitutes a state function? It appears that the French courts, though cognizant of the difficulties encountered when the state penetrates into spheres of activity normally reserved to private entrepreneurs, are inconsistent in their solution to this balancing.

In the early Igoo's the French judiciary began to articulate its retreat from a blind adherence to the doctrine of absolute immunity. Beginning with the judgment of the Cour de cassation in Association France-Export, the French have shown their willingness to construe certain acts of state trading interests as jure gestionis and consequently to deny immunity from jurisdiction in those instances. The French courts have shown themselves predisposed to attach liability upon a statecreated entity in activities defined within the jure gestionis category. This is especially true if the state as a matter of policy has transformed commerce into a state monopoly and seeks to clothe the monopoly agency with the immunity belonging to the state.

But the treatment of immunity from jurisdiction is only a partial solution to the larger balancing problem. The French courts have divided the immunity claimed by state trading interests into two distinct segments, one being immunity from jurisdiction mentioned above, and the other being immunity from execution. ${ }^{57}$ The distinction operates to the extent that a denial or waiver of the former does not necessarily constitute a denial or waiver of the latter. Thus, a court which will deny immunity from jurisdiction may later reverse itself and grant immunity from execution in the same litigation. Hence, though the courts are amenable to a denial of immunity from jurisdiction, litigants must continually face the prospect of a denial of execution on a previously awarded judgment.

The most recent pronouncement on the issue of immunity from execution was contained in the Clerget case. This case would appear to put an end to the jurisprudential uncertainty surrounding a state trading interest's claim to immunity from execution. And without a doubt, the Cour de cassation approved the court of appeal's having, in the name of the sovereignty and independence of a foreign state, declared unacceptable the execution of the judgment on the funds of the Democratic Republic. Furthermore, the Cour de cassation specifies that immunity from execution should be granted even for the payment of debts having their origin in acts of management relating to private rights.

\footnotetext{
${ }^{67}$ See Freyria, Les limites de limmunité de juridiction et d'éxecution des Etats étrangers, 40 Rever 449 (195I).
} 
But the treatment of immunity from execution claimed by a state trading interest is far from settled. The judgment as reported in Clerget is very precise in noting that the funds held by the Banque commorciale could not be attached, since their origin and their use could not be determined. Can one not legitimately infer that if a distinction could be made between the funds used for public activities and the funds serving commercial activities, the Cour de cassation would not have allowed immunity from execution over the entire funds? ${ }^{58}$ To suggest otherwise would allow the simplistic solution of the Cour de cassation to remove previously enunciated restrictions on immunity from execution and reinstate the absolute character of immunity from execution in France, a result of uncertain contribution to the security of legal transactions with foreign states.

\footnotetext{
${ }^{53}$ Compare Englander v. Statni Banka Czechoslovaka, [1969] Bull. Civ, I. 52, No. 69, 96 JournaL 923 ( 1969 ) (Cass. civ. lre).
} 